\title{
FAKTOR-FAKTOR YANG BERHUBUNGAN DENGAN PENYALAHGUNAAN NARKOBA PADA REMAJA
}

\author{
Mailiza Cahyani
}

Akademi Kebidanan Satu Enam Lima Pekanbaru

\begin{abstract}
ABSTRAK
Narkoba adalah singkatan dari Narkotika, Psikotropika dan bahan adiktif lainnya. Pada tahun 2008 pengguna narkoba berjumlah 3,3 juta orang, dimana sekitar $93 \%$ berada pada kelompok usia produktif yaitu umur 15-34 tahun dan 90\% dari kelompok coba pakai narkoba adalah pelajar. Beberapa penyebab penyalahgunaan narkoba adalah pengaruh orang tua, struktur keluarga, teman sebaya, pengetahuan, sikap dan keyakinan. Tujuan penelitian ini untuk mengetahui faktor-faktor yang berhubungan dengan penyalahgunaan narkoba pada remaja di Lembaga Pemasyarakatan kelas II Kota Pekanbaru. Jenis penelitian ini adalah analitik dengan desain penelitian cross sectional. Sampel dalam penelitian ini adalah remaja yang menjadi tahanan di Lembaga Pemasyarakatan Kelas II Kota Pekanbaru berjumlah 212 orang dengan menggunakan systematic random sampling. Analisa data meliputi analisis univariat, bivariat dengan uji chi square, multivariat dengan uji regresi logistic ganda.Hasil penelitian diperoleh proporsi bahwa remaja yang melakukan penyalahgunaan narkoba di Lembaga Pemasyarakatan Kelas II Kota Pekabaru berjumlah 176 (83\%), variabel yang berhubungan dengan penyalahgunaan narkoba adalah kesibukan orang tua (POR:4,656;95\%CI:1,651-13,130), Teman sebaya (POR:5,012;95\%CI:1,594-15,762) dan Lingkungan masyarakat (POR:11,325;95\%CI:3,966-32,337). Kesimpulan dalam penelitian ini adalah bahwa ada hubungan antara kesibukan orang tua, teman sebaya dan lingkungan masyarakat dengan penyalahgunaan narkoba. Saran bagi remaja, bergaul dengan teman sebaya yang berprilaku positif, aktif dalam kegiatan PIK (Pusat Informasi Konseling). Bagi orang tua, menciptakan ikatan keluarga yang kuat melalui hubungan emosional dan memberikan perhatian dan kasih sayang yang baik.
\end{abstract}

Kata Kunci : Kesibukan orang tua, teman sebaya, lingkungan masyarakat, penyalahgunaan narkoba

\section{PENDAHULUAN}

Kehamilan merupakan suatu proses dari kehidupan wanita, di mana dengan adanya proses ini akan menyebabkan perubahan pada ibu tersebut, yang meliputi perubahan fisik, mental, dan sosialnya. Dalam perubahanperubahan tentunya tak lepas dari adanya faktor-faktor yang memengaruhinya, yaitu faktor fisik, psikologis, lingkungan, sosial, budaya, serta ekonomi (Dewi, dkk. 2011).

Penyalahgunaan narkoba pada remaja adalah Pemakaian narkoba pada remaja dapat merusak kehidupan yang produktif pada pemakainya. Prilaku penyalahgunaan narkoba dikalangan remaja tidak jarang merenggut nyawa si pemakainya. Jika hal ini terus berlanjut, maka tidak mustahil bangsa Indonesia akan mengalami generasi yang hilang (The lost generation), karena remaja sebagai generasi yang diharapkan menjadi penerus bangsa, semakin hari semakin rapuh digerogoti zat-zat adiktif penghancur syaraf. Sehingga remaja tersebut tidak dapat berpikir jernih dan tidak dapat menjalankan tugas dan perannya sebagai remaja yang produktif dan berdampak terhadap kesehatan reproduksinya. Akibatnya, generasi harapan bangsa yang sehat, tangguh dan cerdas hanya akan tinggal kenangan (Rozak dkk, 2009).

Permasalahan narkoba merupakan ancaman besar bagi bangsa Indonesia, khususnya generasi muda. Penyalahgunaan narkoba pada remaja berhubungan erat terhadap masalah kesehatan reproduksi yaitu prilaku seks pra nikah, HIV/AIDS dan penyebaran virus hepatitis melalui jarum suntik yang pada akhirnya dapat menyebabkan kematian (BKKBN, 2011). 
Berkembangnya penyalahgunaan narkoba pada remaja disebabkan oleh beberapa faktor antara lain, faktor diri sendiri yaitu: pengetahuan, rasa ingin tahu, ingin bebas dari rasa sakit, sikap, keyakinan, faktor keluarga, faktor teman sebaya, lingkungan masyarakat (Partodihardjo, 2011).

Pada tahun 2008 penyalahgunaan Narkoba di Indonesia berjumlah 3,3 juta orang dimana sekitar $93 \%$ berada pada kelompok usia produktif yaitu umur 15-34 tahun dan 90\% dari kelompok coba pakai narkoba adalah pelajar (sekolah menengah pertama dan sekolah menengah atas). Diperkirakan pada tahun 2015 jumlah penyalahgunaan Narkoba sekitar 5,1 juta orang jika upaya pencegahan, pemberantasan, penyalahgunaan dan peredaran gelap narkoba tidak berjalan efektif (BNN, 2012).

Dalam catatan kepolisian Dikrektorat Tindak Pidana Narkoba Mabes Polri, Maret 2012 diketahui kasus penyalahgunaan narkoba dikalangan remaja dari tahun ketahun semakin meningkat. Pada tahun 2010 kasus narkoba yang menimpa remaja berjumlah 1603 kasus dan pada tahun 2011 berjumlah 1888 kasus.

Menurut BNN tahun 2013 Provinsi Riau dikategorikan sebagai salah satu Provinsi terbesar jumlah konsumen narkoba yaitu 110.000 jiwa pecandu atau penyalahguna narkoba. Hasil data dari Rumah Sakit Jiwa Pekanbaru pada bulan Desember tahun 2013 terdapat 53 orang pasien pengguna narkoba. Pasien pengguna narkoba yang dirawat di Rumah Sakit Jiwa merupakan pengguna narkoba dengan gangguan jiwa.

Data yang didapatkan dari Lembaga Pemasyarakatan Kelas II Kota Pekanbaru, pada bulan Desember tahun 2013 diketahui: Lembaga Pemasyarakatan dihuni oleh 1240 orang narapidana dengan 643 kasus $(50,24 \%)$ terlibat kasus narkoba dan remaja berjumlah 431 orang dengan $114(26,45 \%)$ kasus narkoba. Di lembaga Pemasyarakatan kelas II Kota Pekanbaru belum pernah dilakukan penelitian tentang faktor yang berhubungan dengan penyalahgunaan narkoba pada remaja.

\section{METODOLOGI PENELITIAN}

Penelitian ini bersifat kuantitatif analitik observasional dengan jenis desain Studi Penampang Analitik (Analytic Crosssectional). Pada penelitian ini sampel yang digunakan yaitu 212 sampel yaitu remaja yang menjadi Tahanan di Lembaga Pemasyarakatan Kelas II Kota Pekanbaru, dengan menggunakan tabel Sample Size for One-Sample Test of Proportion (Level of Significance 5\%; Power 90\%; Alternatif Hypotesis; I-side. Prosedur pengambilan sampel yang dilakukan secara systematic random sampling. Jenis data yang dikumpulkan adalah data primer, yaitu data yang langsung didapatkan dari responden, dikumpulkan dengan teknik membagikan kuesioner dengan cara menanyakan apa yang ada pada variabel independen. Analisia univariat dilakukan untuk memperoleh informasi tentang kategori yang beresiko dan juga untuk mengetahui data yang relatif homogeny bila proporsi dari salah satu kategorinya $<15 \%$ Analisa Bivariat menggunakan indikator Prevalence Odd Ratio (POR) dan analisis regresi logistik untuk Analisia Multivariati.

\section{HASIL DAN PEMBAHASAN}

Hasil analisis univariat didapatkan remaja yang menggunakan narkoba 176 orang (83,0 $\%$ ), remaja berpengetahuan tinggi sebanyak 127 orang $(59,9 \%)$, remaja memiliki orang tua yang sibuk 159 orang (75\%), remaja tidak mempunyai riwayat keluarga 127 orang $(59,9 \%)$, teman sebaya mempengaruhi remaja sebanyak 143 orang $(67,5 \%)$, lingkungan masyarakat mempengaruhi remaja sebanyak 171 orang $(80,7 \%)$, remaja penyalahguna narkoba berpendidikan tinggi 115 orang $(54,2 \%)$.

Hasil analisis bivariat terhadap 6 variabel, terdapat 4 variabel yang mempunyai hubungan yang signifikan dengan penyalahgunaan narkoba pada remaja yaitu pengetahuan (pvalue $=0,027$ ), kesibukan orangtua (pvalue $=0,000$ ), teman sebaya (pvalue $=0,000$ ), lingkungan masyarakat (pvalue $=0,000$ ). Sedangkan 
variabel riwayat keluarga dan pendidikan tidak bermakna secara statistik (lihat tabel 1).

Hasil analisa multivariate dapat disimpulkan bahwa variabel yang berhubungan secara signifikan dengan penyalahguna narkoba pada remaja adalah kesibukan orang tua dengan nilai $\mathrm{OR}=4,656$, teman sebaya dengan nilai $\mathrm{OR}=5,012$ dan lingkungan masyarakat dengan nilai $\mathrm{OR}=11,325$. Variabel confounding yaitu variabel pengetahuan terhadap variabel kesibukan orangtua dan teman sebaya.

Tabel. 1. Resume Hasil Analisis Bivariat

\begin{tabular}{|c|c|c|c|c|c|c|c|}
\hline \multirow{3}{*}{ Variabel } & \multicolumn{5}{|c|}{ Penyalahgunaan Narkoba } & \multirow{3}{*}{$\begin{array}{c}P \\
\text { Value }\end{array}$} & \multirow{3}{*}{$\begin{array}{c}\text { POR } \\
(95 \% \mathrm{CI})\end{array}$} \\
\hline & \multicolumn{2}{|c|}{$\begin{array}{c}\text { Mengguna } \\
\text { kan }\end{array}$} & \multicolumn{2}{|c|}{$\begin{array}{c}\text { Tidak } \\
\text { Menggunakan }\end{array}$} & \multirow{2}{*}{$\begin{array}{l}\text { Total } \\
\text { n (\%) }\end{array}$} & & \\
\hline & $\mathbf{N}^{\mathrm{n}}$ & $\%$ & $\mathbf{N}$ & $\%$ & & & \\
\hline \multicolumn{8}{|l|}{ Pengetahuan } \\
\hline Rendah & 77 & 90,5 & 8 & 9,5 & $85(100)$ & \multirow[t]{3}{*}{$\mathbf{0 , 0 2 7}$} & 2,722 \\
\hline Tinggi & 99 & 78 & 28 & 22 & $127(100)$ & & $(1,175-6,307)$ \\
\hline Total & 176 & 83,0 & 36 & 17,0 & $212(100)$ & & \\
\hline \multicolumn{8}{|l|}{ Kesibukan orang tua } \\
\hline Sibuk & 146 & 91,8 & 13 & 8,2 & $159(100)$ & \multirow[t]{3}{*}{$\mathbf{0 , 0 0 0}$} & 8,610 \\
\hline Tidak sibuk & 30 & 56,6 & 23 & 43,4 & $53(100)$ & & $(3,926-$ \\
\hline Total & 176 & 83,0 & 36 & 17,0 & $212(100)$ & & $18,885)$ \\
\hline \multicolumn{8}{|l|}{ Riwayat keluarga } \\
\hline Ada & 73 & 85,9 & 12 & 14,1 & $85(100)$ & \multirow[t]{3}{*}{0,470} & 1,417 \\
\hline Tidak & 103 & 81,1 & 24 & 18,9 & $127(100)$ & & $(0,666-3,016)$ \\
\hline Total & 176 & 83,0 & 36 & 17,0 & $212(100)$ & & \\
\hline \multicolumn{8}{|l|}{ Teman sebaya } \\
\hline Mempengaruhi & 137 & 95,8 & 6 & 4,2 & $143(100)$ & \multirow[t]{3}{*}{$\mathbf{0 , 0 0 0}$} & 17,564 \\
\hline Tidak mempengaruhi & 39 & 56,5 & 30 & 43,5 & $69(100)$ & & $(6,820-$ \\
\hline Total & 176 & 83,0 & 36 & 17,0 & $212(100)$ & & $45,232)$ \\
\hline \multicolumn{8}{|l|}{ Lingkungan masyarakat } \\
\hline Mempengaruhi & 162 & 94,7 & 9 & 5,3 & $171(100)$ & \multirow[t]{3}{*}{$\mathbf{0 , 0 0 0}$} & 34,714 \\
\hline Tidak mempengaruhi & 14 & 34,1 & 27 & 65,9 & $41(100)$ & & $(13,680-$ \\
\hline Total & 176 & 83,0 & 36 & 17,0 & $212(100)$ & & $88,093)$ \\
\hline \multicolumn{8}{|l|}{ Pendidikan } \\
\hline Tinggi & 97 & 84,3 & 18 & 15,7 & $115(100)$ & \multirow[t]{3}{*}{0,706} & 1,228 \\
\hline Rendah & 79 & 81,4 & 18 & 18,6 & $97(100)$ & & $(0,599-2,517)$ \\
\hline Total & 176 & 83,0 & 36 & 17,0 & $212(100)$ & & \\
\hline
\end{tabular}

Tabel. 2. Permodelan Terakhir Multivariat

\begin{tabular}{clcccc}
\hline \multirow{2}{*}{ No } & \multicolumn{1}{c}{ Variabel } & \multirow{2}{*}{ P value } & POR & Lower & Upper \\
\hline 1 & Pengetahuan & 0,142 & 2,358 & 0,751 & 7,406 \\
2 & Kesibukan orang tua & 0,004 & 4,656 & 1,651 & 13,130 \\
3 & Teman sebaya & 0,006 & 5,012 & 1,594 & 15,762 \\
4 & Lingkungan masyarakat & 0,000 & 11,325 & 3,966 & 32,337 \\
\hline
\end{tabular}

Faktor yang berhubungan dengan penyalahgunaan narkoba pada remaja

\section{Kesibukan orang tua}

Remaja yang orang tuanya sibuk berisiko 4 kali untuk melakukan penyalahgunaan narkoba dibandingkan remaja yang orang tuanya tidak sibuk $(95 \% \mathrm{CI}=1,651-13,130)$. Orang tua yang mempunyai kesibukan dan kurang melakukan komunikasi kepada anak, membuat anak merasa tidak mendapatkan perhatian dan kasih sayang dari orang tuanya tersebut. Banyak anak menggantungkan diri kepada orang lain yang dianggapnya bisa memberikan kasih sayang sehingga anak pergi dari rumah guna melampiaskan kekesalan dan menjadikan narkoba sebagai pelarian. Remaja menganggap narkoba dapat memberikan ketenangan dan dapat menghilangkan semua beban yang terjadi. 
Penelitian ini sesuai dengan penelitian yang dilakukan oleh Afrinisna (2010) dan Rustyawati (2010), bahwa tidak sempurnanya struktur dalam keluarga dapat membuat peran dan kekuatan keluarga melemah, peran setiap anggota keluarga tidak berfungsi dengan baik sehingga dapat terjadi penyalahgunaan narkoba pada remaja. Untuk itu sebaiknya diupayakan agar orang tua mengerti bahwa mereka mempunyai peran yang penting terhadap prilaku remaja dan pentingnya komunikasi dan selalu memberikan perhatian dan kasih sayang yang cukup kepada remaja.

\section{Teman Sebaya}

Remaja yang mempunyai teman sebaya penyalahguna narkoba berisiko 5 kali melakukan penyalahgunaan narkoba dibandingkan remaja yang tidak mempunyai teman sebaya pengguna narkoba (95\% CI=1,594-15,762). Perasaan setia kawan sangat kuat dimiliki oleh generasi muda. Jika tidak mendapatkan penyaluran yang positif, maka sifat positif tersebut dapat berubah menjadi negatif. Prilaku penyalahgunaan narkoba pada remaja berkaitan antara remaja dengan lingkungannya. Remaja menggunakan narkoba disebabkan karena banyaknya teman yang menggunakan narkoba, menjadi pengedar dan mendapat tekanan jika tidak mengikuti kemauan mereka.

Penelitian ini sesuai dengan penelitan yang dilakukan Rustyawati (2010), bahwa perasaan setia kawan sangat kuat dimiliki oleh generasi muda. Jika tidak mendapatkan penyaluran yang positif, sifat positif tersebut dapat berbahaya dan menjadi negatif. Jika temannya melakukan penyalahgunaan narkoba, maka ia ikut melakukan penyalahgunaai narkoba. Untuk itu sebaiknya diupayakan penyuluhan secara kontinu di sekolah dan karang taruna tentang besarnya pengaruh teman sebaya dalam penyalahgunaan narkoba dan diharapkan remaja terlibat dalam organisasi PIK (Pusat Informasi Konseling) Sehingga remaja mempunyai pengetahuan yang tinggi tentang penyalahgunaan narkoba dan mempunyai teman sebaya yang berprilaku positif.

\section{Lingkungan Masyarakat}

Remaja yang tinggal di lingkungan masyarakat mempengaruhi berisiko 11 kali melakukan penyalahgunaan narkoba (95\% CI=3,966-32,337). Remaja yang tinggal dilingkungan masyarakat yang buruk dapat menjadi pengguna narkoba dibandingkan remaja yang tinggal dilingkungan masyarakat yang bagus.

Penelitian ini sesuai dengan penelitian yang dilakukan oleh Handoyo (2004) dan Corina (2010) bahwa lingkungan tempat tinggal remaja banyak dihuni oleh para pengguna narkoba tentu remaja dapat mellihat prilaku pengguna narkoba tersebut yang dapat menimbulkan keinginan untuk mencoba dan merasakan bagaimana narkoba. Untuk itu diupayakan agar tokoh masyarakat setempat menjaga lingkungan dengan baik, jika ada lingkungan yang tidak baik agar dapat dirubah ke hal yang positif seperti membuat karang taruna, menyediakan sarana olah raga, dan bagi remaja supaya dapat menghindari lingkungan masyarakat yang negatif dan aktif diremaja mesjid.

Faktor yang tidak berhubungan dengan penyalahgunaan narkoba pada remaja

\section{Riwayat Keluarga}

Hasil analisis multivariat, menunjukkan bahwa tidak ada hubungan tidak ada hubungan antara riwayat keluarga dengan penyalahgunaan narkoba, dimana diperoleh nilai tidak bermakna secara statistik (P value $=$ $0,359)$. Pertanyaan tentang riwayat keluarga susah dijawab responden karena mereka tidak mengetahui apakah keluarga mereka ada yang melakukan penyalahgunaan narkoba.

\section{Pendidikan}

Hasil penelitian menunjukkan tidak ada hubungan pendidikan dengan penyalahgunaan narkoba, dimana diperoleh nilai tidak bermakna secara statistik (P value $=0,575)$. Semakin tinggi tingkat pendidikan seseorang maka akan bertambah pengalaman yang mempengaruhi wawasan dan pengetahuan, sebaliknya tingkat 
pendidikan rendah maka tidak banyak informasi yang didapat dalam memecahkan suatu masalah. Teori ini berbeda dengan hasil penelitian dan penelitian yang dilakukan oleh Jaji, bahwa remaja yang berisiko melakukan penyalahgunaan narkoba pada remaja yaitu tingkat pendidikan tinggi sebesar $(62,5 \%)$.

\section{KESIMPULAN DAN SARAN}

Dari hasil analisis multivariat, variabel yang berhubungan secara signifikan dengan penyalahgunaan narkoba pada remaja yaitu kesibukan orang tua dengan nilai OR 4,656, artinya remaja dengan orang tua yang sibuk mempunyai risisko 4 kali untuk melakukan penyalahgunaan narkoba. Teman sebaya dengan nilai OR 5,012, artinya remaja yang mempunyai teman sebaya mempengaruhi berisiko 5 kali melakukan penyalahgunaan narkoba dan Lingkungan masyarakat dengan nilai OR 11,325 , artinya remaja yang tinggal di lingkungan masyarakat mempengaruhi berisiko 11,3 kali melakukan penyalahgunaan narkoba.

\section{Saran}

Memberikan penyuluhan kepada orang tua, agar orang tua mengerti bahwa mereka mempunyai peran yang penting terhadap prilaku remaja, pentingnya melakukan komunikasi, selalu memberikan perhatian dan kasih sayang yang cukup kepada remaja. Memberi penyuluhan terhadap tokoh masyarakat setempat agar menjaga lingkungan dengan baik. Jika ada lingkungan yang tidak baik agar dapat dirubah ke hal yang positif seperti membuat karang taruna, menyediakan sarana olah raga, bagi remaja supaya dapat menghindari lingkungan masyarakat yang negatif dan aktif diremaja mesjid. Dilaksanakan penyuluhan secara kontinu di sekolah, karang taruna tentang besarnya pengaruh teman sebaya dalam penyalahgunaan narkoba. Diharapkan remaja terlibat dalam organisasi PIK (Pusat Informasi Konseling) sehingga remaja mempunyai pengetahuan yang tinggi tentang penyalahgunaan narkoba dan mempunyai teman sebaya yang berprilaku positif.

\section{DAFTAR PUSTAKA}

Afrinisna, R (2010). Penyebab dan Kondisi Psikologis Narapidana Kasus Narkoba PadaRemaja (http://journal.uad.ac.id/index.php/EMP ATHY/article/view/1561)

Andriyani, $\mathrm{T}$ (2011). Upaya pencegahan Tindak Penyalahgunaan Narkoba Di Kalangan Mahasiswa Politeknik Negeri Sriwijaya. Politkenik Negeri Sriwijaya. Jurnal Ilmiah Orasi Bisnis-ISSN: 20851375 Edisi Ke-VI, Novemver 20122

Asni M, Rahma, Sarake, M (2013). Faktor Yang Berhubungan Dengan Penyalahgunaan Narkotika dan Bahan Adiktif (Narkoba) Pada Remaja Di SMA Kartika Wirabuana XX-1 Makasar Tahun 2013 (http://repository.unhas.ac.id/bitstream/ handle/123456789/5514/jurnal.pdf?seq uence=1)

Badan Koodinator Keluarga Berencana Nasional (2011), Kajian Profil Penduduk Remaja. Pusat Penelitian dan Pengembangan Kependudukan. Seri 1 No. 6/Pusdu-BKKBN/ Desember 2011

Badan Narkotika Nasional (2008). Petunjuk Teknis Advokasi Bidang Pencegahan Penyalahgunaan Narkoba Bagi Lembaga/ Instansi Pemerintah. Jakarta

Badan Narkotika Nasional (2011). Survey Nasional Perkembangan Penyalahgunaan Narkoba di Indonesia Tahun 2011. Jakarta

Badan Narkotika Nasional (2012a). Mahasiswa dan Bahaya Narkotika. Jakarta. Direktorat Diseminasi Informasi, Deputi Bidang Pencegahan

Badan Narkotika Nasional (2012b). Narkotika Dalam Pandangan Agama. Jakarta. Direktorat Diseminasi Informasi, Deputi Bidang Pencegahan

Badan Narkotika Nasional (2012c). Pencegahan Penyalahgunaan Narkoba Bagi Remaja. Jakarta. Direktorat Diseminasi Informasi, Deputi Bidang Pencegahan. 
Corina, N (2010). Faktor-faktor yang mempengaruhi remaja pengguna narkoba di Lapas Klas II B Anak Kota Pekanbaru Tahun 2010. Pekanbaru. STIKES Hang Tuah

Hawari, Dadang. (2002). Konsep Agama (Islam) menanggulangi NAPZA. Jakarta. PT Dana Bhakti Prima Yasa

Herdawati, N (2010). Faktor-faktor dalam keluarga yang mempengaruhi remaja terhadap penyalahgunaan narkoba di klas II B anak Kota Pekanbaru tahun 2010. Pekanbaru. STIKES Hang Tuah

Hikmat, Mahi M (2007). Awas Narkoba, para Remaja waspada. Bandung. PT. Grafitri Budi utami

Hidayati, P (2012). Gambaran Pengetahuan dan Upaya Pencegahan terhadap Penyalhgunaan Narkoba Pada Remaja Di SMK Negeri 2 Sragen Kabupaten Sragen. STIKES 'Aisyiyah Surakarta. Gaster, Vol. 9, No.1 Februari 2012

Indiyah (2005). Faktor-faktor Penyebab Penyalahgunaan napza: Studi Kasus Pada Narapidana di LP Klas II A Wirogunan Yogyakarta

(http://journal.ui.ac.id/index.php/jki/article/vie w/1243)

Jaji (2009). Hubungan Faktor Sosial dan Spritual Dengan Risiko Penyalahgunaan Napza Pada Remaja SMP dan SMA di Kota Palembang 2009 (http://eprints.unsri.ac.id/752/)

Jiloha, R (2009) Social and Cultural Aspects of Drug Abuse in Adolescents (http://medind.nic.in/daa/t09/i2/daat09i 2p167.pdf)

Komisi Penaggulangan AIDS (2008). Pedoman Prosedur Pelaksanaan Program Pengurangan Dampak Buruk Bagi Pengguna Napza Suntik Di Puskesmas. Jakarta

Lapau, B (2012) Metode Penelitian Kesehatan.

Jakarta. Yayasan Pustaka Obor Indonesia.

Lestari, H (2007) Perilaku Beresiko Remaja Di Indonesia Menurut Survey Kesehatan Reproduksi Remaja Indonesia (SKRRI)
Tahun 2007. Jakarta. Badan Litbangkes, Kementrian kesehatan.

Lisa, J. 2013. Narkoba Psikotropika dan Ganggguan Jiwa. Jakarta: Nuha Medika.

Lubis, S (2012). Hubungan Faktor Internal dan Faktor Eksternal Dengan Kekambuhan Kembali Pasien Penyalahguna Napza di Kabupaten Deli Serdang. Universitas Sumatera Utara

Martono, L,. Joewana, S (2006) Pencegahan Dan Penyalahgunaan Narkoba Berbasis Sekolah. Jakarta. Balai Pustaka

Nurhaeni, H., Chairani, R (2009). Hubungan Dukungan Sosial Terhadap Depresi Remaja Mantan Penyalahgunaan Napza di Lembaga Pemasyarakatan Kelas IIA Pondok bambu Jakarta Timur Tahun 2009

(http:ejournal.litbang.depkes.go.id/index.php/h sr/article/download/.../2184)

Ondieki, A (2012) The Preconditoning Factors to Drug Use and abuse among Secondary School Adolescents in Kiamokma Division, Kisii Country (http://connection.ebscohost.com/c/arti cles/80021193/preconditioning-factorsdrug-use-abuse-among-secondary$\underline{\text { school-adolescents-kiamokma-division- }}$ kisii-county)

Poltekkes Depkes (2010). Kesehatan Remaja Problem Dan Solusinya. Jakarta. Salemba Medika

Partodihardjo, S (2011). Kenali Narkoba dan Musuhi Penyalahgunaannya. Jakarta. Erlangga

Pribadi, H., Banowati, L(2007). Tidak Cukup Berkata Tidak Pada Narkoba Bagi Pemuda dan Pelajar SMP/MTS. Jakarta. Cakra Media

Rustyawati (2010). Beberapa Faktor Risiko yang Berhubungan Dengan Penyalahgunaan Narkoba Pada Penderita Yang Dirawat Di Panti Rehabilitas (http://eprints.undip.ac.id/4607/)

Sirait, Betty A., Tambunan, C (2002). Remaja Sebagai Target NAPZA 
(http://www.substansiceria-

bkkbn go id bj htm)

Soetjiningsih (2004). Tumbuh kembang Remaja dan Permasalahannya. Jakarta. Sagung

Seto.

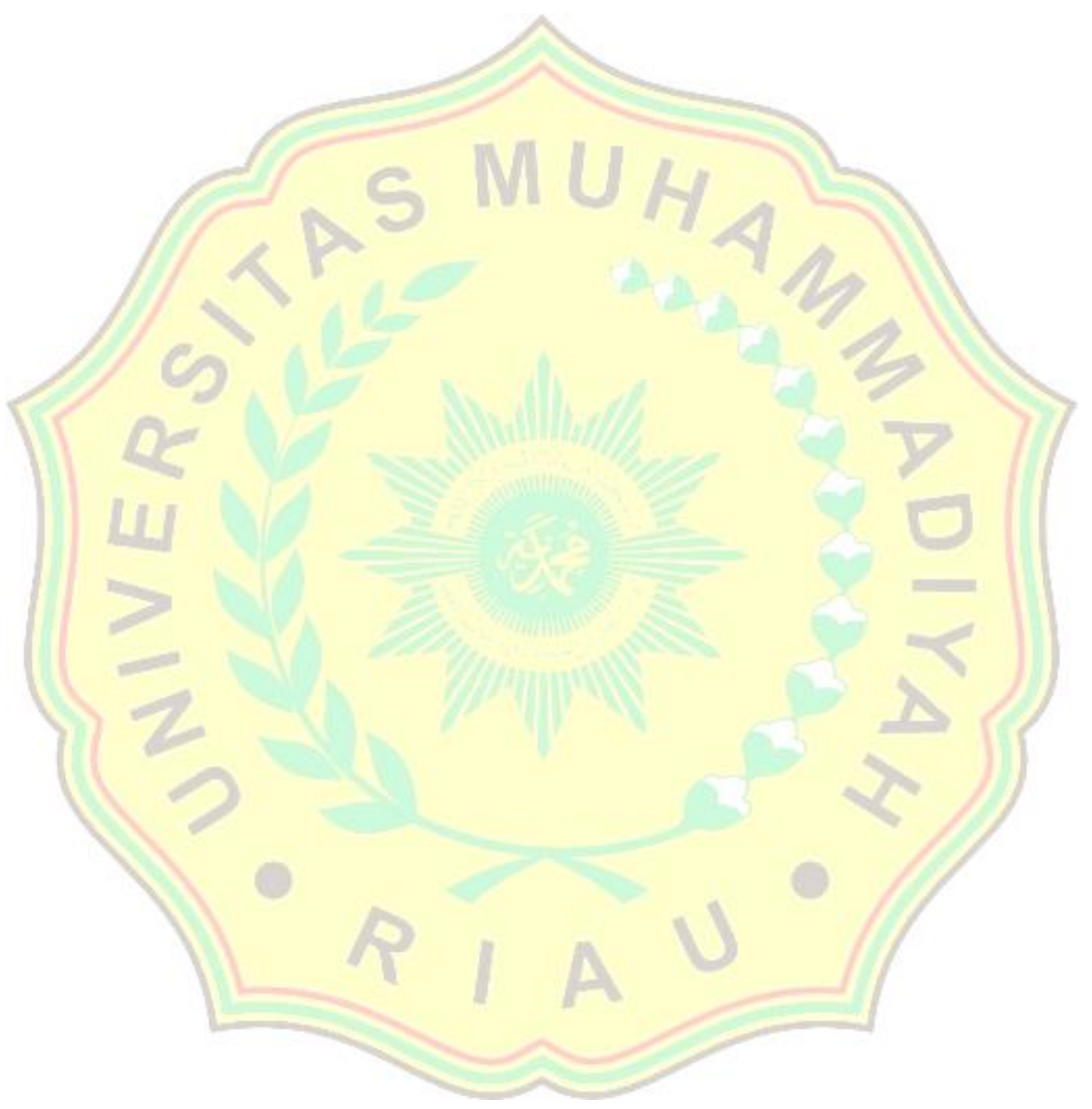


